\title{
DEVELOPMENT OF ENGLISH TEACHING MATERIALS WITH POSTER PRESENTATION ASSISTED VLOG
}

\author{
Rasmita \\ Universitas Putra Indonesia YPTK Padang, Sumatera Barat, Indonesia \\ Email: mi2t.caem85@gmail.com \\ Shally Amna \\ Universitas Putra Indonesia YPTK Padang, Sumatera Barat, Indonesia \\ Email: shallyamna@upiyptk.ac.id
}

DOI: 10.35445/alishlah.v12.i2.194

Accepted: May $1^{\text {st }}, 2020$. Approved: August $10^{\text {th }}, 2020$

Published: December $30^{\text {th }}, 2020$

\begin{abstract}
The purpose of this research is to produce English language teaching materials 1 through the implementation of poster presentation assisted vlog strategies for improving language skills and student learning outcomes at private Universities in Padang. This research uses research and development (R\&D) methods. The stages of development in this study using the development procedures of the Puslitjaknov team include; (1) needs analysis, (2) initial product development, (3) expert validation and revision, (4) small-scale field trials, (5) large-scale field trials. Data collection methods in this study are the observation sheets, questionnaires, expert validation sheets and evaluation (tests). The results of this development research are effective and applicable English 1 teaching materials used for non-English major students.
\end{abstract}

Keywords: Bahan Ajar, Poster Presentation, Vlog.

\section{PENGEMBANGAN BAHAN AJAR MATA KULIAH BAHASA INGGRIS DENGAN POSTER PRESENTATION BERBANTUAN VLOG}

\begin{abstract}
Abstrak
Tujuan dari penelitian ini adalah untuk menghasilkan bahan ajar Bahasa Inggris 1 melalui implementasi strategi poster presentation berbantuan vlog untuk meningkatkan kemampuan berbahasa dan hasil belajar mahasiswa di perguruan tinggi swasta di Kota Padang. Penelitian ini menggunakan metode penelitian dan pengembangan $(R \& D)$. Tahapan pengembangan dalam penelitian ini mengunakan prosedur pengembangan dari Tim puslitjaknov meliputi; (1) analisis
\end{abstract}


Al-Ishlah: Jurnal Pendidikan - ISSN: 2087-949o (p); 2597-940X (e)

Vol. 12, No. 2 (2020)

kebutuhan, (2) pengembangan produk awal, (3) validasi ahli dan revisi, (4) uji coba lapangan skala kecil, (5) uji coba lapangan skala besar. Metode pengumpulan data dalam penelitian ini adalah lembar observasi, angket, lembar validasi ahli dan evaluasi (test). Hasil penelitian pengembangan ini berupa bahan ajar mata kuliah Bahasa Inggris 1 yang efektif dan aplikatif yang digunakan untuk mahasiswa non jurusan Bahasa Inggris.

Kata kunci: bahan ajar, poster presentation, vlog.

\section{PENDAHULUAN}

Pembelajaran Bahasa Inggris tidak hanya sekedar pemberian materi, topik ataupun konsep yang strategis, tetapi juga memberikan pengalaman belajar dan kemandirian mahasiswa. Salah satu faktor penunjang kemandirian tersebut adalah ketersediaan sumber belajar memadai seperti buku teks/bahan ajar yang terintegrasi pada mata kuliah tersebut. Hasil observasi pada semester ganjil 2017/2018 diperoleh beberapa fakta, antara lain proses pembelajaran mata kuliah Bahasa Inggris di kelas masih tergolong umum yaitu dengan metode ceramah (teacher centered), media dipakai berupa buku ajar atau modul, papan tulis dan power poin. Dalam proses belajar mengajar, mahasiswa hanya mendengarkan penjelasan materi dari dosen, menyalin ulang apa yang telah disampaikan dosen dan mengerjakan latihan soal, sehingga tingkat kelulusan Bahasa Inggris kurang memuaskan, hanya mencapai $40 \%$ mahasiswa setiap tahunnya..

Melihat fakta yang terjadi, perlu evaluasi pelaksanaan kegiatan perkuliahan pada mata kuliah Bahasa Inggris serta mengkaji penyebabnya. Setelah diobservasi, rendahnya hasil belajar mahasiswa disebabkan dari beberapa faktor yaitu: (1) jumlah jam untuk pelajaran Bahasa Inggris tidak cukup untuk memberikan teori secara menyeluruh, (2) jumlah mahasiswa di dalam kelas yang tidak memungkinkan untuk melakukan praktek per-individu, (3) lemahnya kepercayaan diri mahasiswa berBahasa Inggris dan (4) kurangnya minat dan motivasi dalam belajar karena metode pembelajaran yang monoton.

Kurang ketersediaannya materi-materi bahan ajar untuk mata kuliah Bahasa Inggris 1 di kampus Universitas Putra Indonesia (UPI) YPTK Padang merupakan sedikit kendala bagi tenaga pengajar atau dosen yang mengampu mata kuliah tersebut. Karena pada umumnya mereka hanya menggunakan referensi bukubuku terbitan dari luar negeri sehingga sebagian mahasiswa mengatakan berdasarkan percakapan informal bahwa bahan ajar yang digunakan tidak menarik, kurang relevan dengan kebutuhan mahasiswa. Sehingga ini menjadi alasan bagi peneliti yang sekaligus juga sebagai tenaga pengajar pengampu mata kuliah Bahasa Inggris untuk merancang sebuah buku berisi bahan ajar Bahasa Inggris 1 yang merupakan general English untuk mahasiswa tahun pertama. 
Al-Ishlah: Jurnal Pendidikan - ISSN: 2087-949o (p); 2597-940X (e)

Vol. 12, No. 2 (2020)

Perkembangan revolusi industry 4.0 telah memberikan cahaya baru dalam dunia belajar-mengajar. Dengan pesatnya perkembangan teknologi, internet, video dan blog telah memperoleh perhatian yang sangat besar dalam dunia pendidikan khususnya ketika media ini telah digunakan dengan sangat luas dalam konteks pembelajaran Bahasa Inggris (Noytim, 2010). Sementara itu, Vlog adalah penggabungan antara video dan blog (Watkins, 2012). Menurut Gao, W., Tian, Y. \& Huang (2010) Vlog adalah bentuk blogging yang menggunakan video sebagai media utamanya,

Ada banyak alasan kenapa video-based blog atau vlog sangat tepat digunakan sebagai teknik pembelajaran Bahasa Inggris dasar diperguruan tinggi. Salah satu alasan yang paling signifikan adalah aktifitas Vlogging membantu siswa untuk meningkatkan waktunya melatih kemampuan berbicara dalam Bahasa Inggris dan aktifitas ini dapat dilatih secara berulang-ulang sehingga memadai untuk dipublikasikan. Aktifitas speaking English sekarang sudah tidak lagi perlu dilakukan di dalam kelas atau secara tradisional (Watkins, 2012). Manfaat berikutnya adalah mahasiswa dapat menggunakan aktifitas ini untuk menumbuhkan kepercayaan diri dan disiplin diri ketika berbicara dalam Bahasa Inggris, khususnya ketika didengarkan dan dilihat oleh orang banyak setelah Vlog dipublikasikan di media sosial (Hung, 2011). Hal ini disebabkan karena pada saat pembuatan vlog mahasiswa merekam kemampuan bicaranya sendiri, menganalisa, mengevaluasi dan kemudian memperbaikinya sebelum mempublikasikannya. Manfaat vlog yang lain adalah bahwa vlog yang telah dipublikasi adakan mendatangkan feedback sehingga vlog dapat menfasilitasi perkembangan kemampuan siswa dalam pembelajaran Bahasa Inggris (Balakrishnan, V. D. \& Puteh, 2014; Watkins, 2012).

Poster presentation (PP) merupakan teknik yang digunakan dalam mengevaluasi hasil belajar mandiri siswa berkelompok sekaligus mempresentasikannya di dalam video atau di depan kelas. Hasil penelitian yang dilakukan oleh Lambert (2012) menunjukan bagaimana PP dapat sangat berguna dalam menilai kemampuan siswa dalam kelompok diberbagai bidang ilmu. Evaluasi yang didapat termasuk hasil dari pemahaman peserta PP dan penilaian dosen yang bersangkutan. Aktifitas ini memakan cukup banyak waktu untuk persiapan, dan feedback akhir dari dosen untuk memastikan validitas poster yang akan dipresentasikan. 'Posters are a hybrid form_-more detailed than a speech but less than a paper, more interactive than either' '(Miller, 2007).

PP memenuhi delapan prinsip yang baik untuk semua kegiatan pembelajaran berdasarkan ketetapan National Society for Experiential Education (2013). Menurut NSEE, fasilitator memainkan peran utama dalam memastikan bahwa prinsip-prinsip pendidikan eksperimental dapat terpenuhi. Setiap aktifitas pembelajaran harus memenuhi delapan prinsip; niat, kesiapan dan perencanaan, 
Al-Ishlah: Jurnal Pendidikan - ISSN: 2087-9490 (p); 2597-940X (e)

Vol. 12, No. 2 (2020)

keaslian, refleksi, orientasi dan pelatihan, pemantauan dan peningkatan berkelanjutan, penilaian dan evalusi serta pengakuan. Berdasarkan kedelapan prinsip tersebut, PP dapat menjadi salah satu penerapan proses pembelajaran Bahasa Inggris yang eksperimental bagi siswa dan dapat diterapkan untuk materi pelajaran dasar Bahasa Inggris di perguruan tinggi.

Untuk mengatasi berbagai faktor tersebut diperlukan perubahan pola pendekatan pembelajaran menjadi student center untuk menjadikan mahasiswa lebih aktif serta penggunaan bahan ajar yang tepat sasaran pada pembelajaran Bahasa Inggris untuk mahasiswa yang bukan dari jurusan Bahasa Inggris. Solusi yang ditawarkan berupa pengimplementasian poster presentation berbantuan vlog bagi mahasiswa dalam memahami materi pelajaran Bahasa Inggris. Alasan pemilihan poster presentation berbantuan vlog ini adalah karena manfaatnya yang efektif dan massive. Beberapa manfaat media poster presentation menurut Plunkett (2010) antara lain presentasi mengunakan poster dapat untuk menjangkau lebih banyak orang daripada presentasi lisan biasa, Poster yang menarik dapat menarik minat orang yang memandangnya. Forester \& Meyer (2015) juga menambahkan bahwa penggunaan video dalam mempelajari bahasa asing akan meningkatkan minat dan hasil belajar peserta didik.

Poster presentation akan dilakukan oleh mahasiswa dikelas untuk memperdalam pemahaman materi Bahasa Inggris dasar serta mempraktekkannya secara langsung. Sementara vlog nantinya dapat dijadikan media diskusi dan review untuk materi yang telah dipelajari selama 14 kali pertemuan. Selain itu, kedua media terintegrasi ini juga dapat memancing kreativitas dan semangat mahasiswa dalam belajar Bahasa Inggris sehingga hasil belajar yang diperoleh nantinya dapat lebih baik dari sebelumnya. Bahan ajar merupakan sarana belajar yang digunakan di tingkat sekolah dan di perguruan tinggi sebagai upaya pendukung proses pembelajaran. Diantara manfaat bahan ajar antara lain sebagai pegangan dalam menentukan metode pembelajaran, dan memberikan kesempatan kepada peserta didik untuk belajar secara mandiri. Berdasarkan uraian diatas, maka merancang bahan ajar untuk mata kuliah Bahasa Inggris 1 untuk mahasiswa tahun pertama di UPI YPTK Padang sangat perlu dilakukan.

\section{METODE PENELITIAN}

Penelitian ini merupakan penelitian pengembangan (research and development). Menurut Sugiyono (2011), penelitian pengembangan merupakan metode penelitian yang digunakan untuk menghasilkan produk tertentu serta menguji keefektifitas produk tersebut. Penelitian ini bertujuan untuk mengembangkan bahan ajar Bahasa Inggris melalui implementasi media poster presentation berbantuan vlog yang diujicobakan di dalam pembelajaran. Populasi penelitian ini adalah mahasiswa tahun pertama yang mengambil mata kuliah Bahasa Inggris 1 pada semester pertama di kampus UPI YPTK Padang, 
Al-Ishlah: Jurnal Pendidikan - ISSN: 2087-949o (p); 2597-940X (e)

Vol. 12, No. 2 (2020)

perkuliahan tahun ajaran 2018/2019. Teknik samplingnya: cluster random sampling.

Bahan ajar Bahasa Inggris yang dikembangkan menggunakan prosedur pengembangan yang diadopsi dari model pengembangan W. R. Borg and M. D. Gall (1989), namun dapat dilakukan lebih sederhana dalam 5 tahap: (1) melakukan analisis produk yang akan dikembangkan), (2) mengembangkan produk awal, (3) validasi ahli dan revisi, (4) ujicoba lapangan skala kecil dan revisi produk, (5) ujicoba lapangan skala besar dan produk akhir (Tim Puslitjaknov, 2008).

Instrument penelitian ini yang digunakan antara lain lembar validasi , angket dan instrument efektifitas. Adapun lembar validasi terkait produk untuk untuk memperoleh data validitas bahan ajar yang dikembangkan, menguji kebenaran konsep dan penyajian materi, yang diberikan validator. Lembar validasi disusun berdasarkan petunjuk Depdiknas terkait pengembangan modul sebagai bahan ajar. Sedangkan angket digunakan sebagai instrument uji praktikalitas , yang terdiri dari angket dosen dan mahasiswa yang didisi setelah mengikuti proses perkuliahan dengan tujuan untuk melihat repon mereka terhadap bahan ajar yang dikembangkan. Selanjutnya Instrument efektifitas berupa alat evaluasi berbentuk test yang dilakukan di awal dan diakhir perkuliahan (pre-test dan posttest).

Dalam penelitian ini, peneliti mengunakan tiga teknik analisis data yaitu analisis validitas, analisis praktikalitas dan analisis efektifitas. Untuk pengukuran tingkat validitas media pembelajaran digunakan skala likert yaitu untuk mengukur sikap, pendapat, dan persepsi seseorang (Sugiyono, 2011). Dengan skala likerts, variabel yang diukur dijabarkan menjadi indikator variabel. Kemudian indikator tersebut dijabarkan sebagai titik tolak untuk menyusun item-item instrument yang berupa pertanyaan atau pernyataan. Setiap item instrumen yang menggunakan skala likert mempunyai gradasi dari positif sampai negatif. Untuk keperluan analisis kuantitatif, maka jawaban tersebut diberi skor.

Tabel 1 Skala Likert

\begin{tabular}{clc}
\hline No & \multicolumn{1}{c}{ Uraian } & Skor \\
\hline 1 & Sangat baik & 5 \\
2 & Baik & 4 \\
3 & Cukup baik & 3 \\
4 & Kurang baik & 2 \\
5 & Tidak baik & 1 \\
\hline
\end{tabular}

Uji validitas instrument test menggunakan rumus Pearson Product Moment, sebagai berikut: 
Al-Ishlah: Jurnal Pendidikan - ISSN: 2087-949o (p); 2597-940X (e)

Vol. 12, No. 2 (2020)

$$
r_{\text {hithmg }}=\frac{n \sum x y-\sum x \sum y}{\sqrt{\left.\left\{n \sum x^{2}-\left(\sum x\right)^{2}\right), n \sum y^{2}-\left(\sum y\right)^{2}\right\}}}
$$

Keterangan :

rhitung $=$ koefisien korelasi

$\mathrm{n} \quad=$ jumlah responden

$\sum \mathrm{x} \quad=$ jumlah skor item

$\sum \mathrm{y} \quad=$ jumlah skor total (seluruh item)

Kaidah keputusan : Jika r-hitung > r-tabel berarti valid, dan jika r-hitung < r-tabel berarti tidak valid (Abdi, 2012). Selanjutnya data uji praktikalitas hasil pengembangan bahan ajar melalui implementasi poster presentation berbantuan vlog untuk meningkatkan hasil belajar mahasiswa ini dianalisis menggunakan rumus persentasi berikut:

Nilai validitas $=($ jumlah semua skor $/$ skor maksimum $) \times 100 \%$

Setelah persentase diperoleh dilakukan pengelompokkan sesuai kriteria yang dimodifikasi dari Purwanto (2009:82) :

$90 \%-100 \%=$ sangat praktis

$80 \%-89 \%=$ praktis

$65 \%-79 \%=$ cukup praktis

$0 \%-64 \%=$ tidak praktis

Terkait analisis hasil efektifitas, dalam penelitian ini ada ujicoba perlakuan dan menganalisa akibat dari perlakuan tersebut. Untuk menganalisis hasil efektifitasnya menggunakan data pre-test dan post-test one group design, menggunakan rumus $t$-test (Arikunto, 2010):

$$
t=\frac{M d}{\sqrt{\frac{\Sigma(x d)^{2}}{N(N-1)}}}
$$

Keterangan :

Md : mean dari devisi (d) antara post- test dan pre- test

$\mathrm{Xd} \quad$ : perbedaan deviasi dengan mean deviasi

$\sum \mathrm{Xd} 2$ : Jumlah kuadrat deviasi $2 \mathrm{Xd}$

$\mathrm{N}$ : Banyaknya subyek

Df : atau db adalah $\mathrm{N}-1$

Rumus tersebut digunakan untuk desain penelitian subyek tunggal yaitu yang observasinya dilakukan pada saat subyek belum mendapat perlakuan dan 
Al-Ishlah: Jurnal Pendidikan - ISSN: 2087-949o (p); 2597-940X (e)

Vol. 12, No. 2 (2020)

setelah subyek mendapat perlakuan. Hasil data dianalisis menggunakan rumus $t$ hitung, apakah perlakuan yang diberikan efektif atau tidak.

\section{HASIL DAN PEMBAHASAN}

Hasil penelitian pada tahap awal adalah berupa tahap analisis kebutuhan (need analysis). Analisis data untuk mengetahui kebutuhan buku ajar Bahasa Inggris dilakukan kepada 181 orang mahasiswa sebagai sampel penelitian yang merupakan mahasiswa pada jurusan sistem informasi pada fakultas ilmu komputer di UPI YPTK Padang yang telah mengikuti perkuliahan Bahasa Inggris 1. Pertimbangan penilaian sampel analisis kebutuhan ini adalah bahwa mahasiswa tersebut telah mengikuti perkuliahan dan dipandang telah mampu memahami kebutuhan akan perlunya sebuah buku ajar untuk mata kuliah Bahasa Inggris. Analisis data dari angket penelitian merujuk konsep Duddley-Evans \& M.J.St. John (2009) meliputi a) wants,means, subjective needs analysis, b)present situation analysis,c) target analysis, d) lack analysis, e)leaning analysi, f)lingustic analysis, $g$ ) the analysis ofwhat is wanted from the couurse dan h) means analysis. Data tersebut diolah dengan formula diadopsi dari (Arikunto, 2010) maka dapat dideskripsikan seperti data pada tabel 1 berikut ini:

Tabel 2 Hasil Analisis Angket Mahasiswa

\begin{tabular}{|c|c|c|c|}
\hline No & Questions & Answer & Percentage $(\%)$ \\
\hline A1 & $\begin{array}{l}\text { As the first year system information student, how } \\
\text { important is English proficiency? }\end{array}$ & Very important & $76.7 \%$ \\
\hline $\mathrm{A} 2$ & $\begin{array}{l}\text { To improve your English proficiency, how often do you } \\
\text { do activities using English out of your English class? }\end{array}$ & Seldom & $52.7 \%$ \\
\hline A3 & $\begin{array}{l}\text { To learn the English language in the first semester, do you } \\
\text { prefer to learn general English or English for Specific } \\
\text { Purposes? }\end{array}$ & General English & $73.3 \%$ \\
\hline B1 & $\begin{array}{l}\text { Was the textbook you used in learning English was the } \\
\text { first publishing and was not up to date? }\end{array}$ & Yes & 77.3 \\
\hline B2 & $\begin{array}{l}\text { Was the textbook you used in learning English easy to be } \\
\text { comprehended? }\end{array}$ & No & 53.3 \\
\hline B3 & $\begin{array}{l}\text { Can the textbook you used in learning English be used as } \\
\text { a self-study? }\end{array}$ & No & 58.7 \\
\hline No & Questions & Answer & $\%$ \\
\hline $\mathrm{C} 7$ & To review English language as general & Important & 54.0 \\
\hline $\mathrm{C} 8$ & $\begin{array}{l}\text { To equalize students' basic English before learning ESP in } \\
\text { the second semester. }\end{array}$ & Important & 58.7 \\
\hline C9 & To learn English at a higher level & Very Important & 54.0 \\
\hline $\mathrm{C} 10$ & To learn Speaking & Very Important & 60.7 \\
\hline $\mathrm{C} 11$ & To learn Grammar & Very Important & 61.3 \\
\hline $\mathrm{C} 12$ & To learn Listening & Very Important & 55.3 \\
\hline $\mathrm{C} 13$ & To learn Reading & Important & 50.7 \\
\hline $\mathrm{C} 14$ & To learn Writing & Very Important & 52.7 \\
\hline D15 & Speaking & Less & 61.3 \\
\hline D16 & Grammar & Less & 64.7 \\
\hline D17 & Listening & Less & 51.3 \\
\hline D18 & Reading & Good & 62.7 \\
\hline D19 & Writing & Good & 62.7 \\
\hline E20a & Listening & Very Important & 40.0 \\
\hline E20b & Speaking & Very Important & 50.7 \\
\hline E20c & Reading & Very Important & 36.7 \\
\hline E20d & Writing & Important & 36.0 \\
\hline E20f & Grammar & Very Important & 52.0 \\
\hline E21a & Pair work & Important & 31.3 \\
\hline
\end{tabular}


Al-Ishlah: Jurnal Pendidikan - ISSN: 2087-949o (p); 2597-940X (e)

Vol. 12, No. 2 (2020)

$\begin{array}{cl}\text { E21b } & \text { Whole class activity } \\ \text { E21c } & \text { Group work } \\ \text { E21d } & \text { Outside class activity } \\ \text { E21f } & \text { Individual work } \\ \text { F22 } & \text { Language Approach in used in a textbook } \\ \text { F23 } & \text { What topics do you want to learn in English class? }\end{array}$

F23 What topics do you want to learn in English class?

$\begin{array}{cc}\text { Very Important } & 33.3 \\ \text { Very Important } & \mathbf{5 6 . 0} \\ \text { Important } & \mathbf{5 0 . 7} \\ \text { Very Important } & 38.7\end{array}$

Mix (Indonesian - English) $\quad 56.0$

1. Introduction

2. Part of Speech

3. Daily Activities

4. Describing People

and Place

5. Past Experience

6. Achievement

7. Etc. \begin{tabular}{clcc} 
No & \multicolumn{1}{c}{$\begin{array}{c}\text { Questions } \\
\text { G24 }\end{array}$} & $\begin{array}{l}\text { What do you expect to get after learning English language } \\
\text { in the first semester? }\end{array}$ & $\begin{array}{c}\text { To improve English as general } \\
\text { Answer }\end{array}$ \\
H25 & What methods of learning English do you want? & Mix (Student-Teacher center) & 88.7 \\
\hline
\end{tabular}

\begin{tabular}{clcc} 
No & \multicolumn{1}{c}{$\begin{array}{c}\text { Questions } \\
\text { G24 }\end{array}$} & $\begin{array}{l}\text { What do you expect to get after learning English language } \\
\text { in the first semester? }\end{array}$ & $\begin{array}{c}\text { To improve English as general } \\
\text { Answer }\end{array}$ \\
H25 & What methods of learning English do you want? & Mix (Student-Teacher center) & 88.7 \\
\hline
\end{tabular}

\begin{tabular}{clcc} 
No & \multicolumn{1}{c}{$\begin{array}{c}\text { Questions } \\
\text { G24 }\end{array}$} & $\begin{array}{l}\text { What do you expect to get after learning English language } \\
\text { in the first semester? }\end{array}$ & $\begin{array}{c}\text { To improve English as general } \\
\text { Answer }\end{array}$ \\
H25 & What methods of learning English do you want? & Mix (Student-Teacher center) & 88.7 \\
\hline
\end{tabular}

Analisis kebutuhan juga didapatkan dari interview terhadap dosen-dosen yang mengampu mata kuliah Bahasa Inggris 1 di fakultas ilmu komputer, mereka berpendapat bahwa modul yang digunakan sebelumnya memiliki beberapa kekurangan antara lain, buku tersebut terbitan lama, sulit dipahami mahasiswa, dan kurang membantu mahasiswa untuk dapat belajar mandiri.

Tahap kedua yaitu tahap develop merupakan tahapan dimana peneliti melakukan penilaian terhadap produk yang telah dikembangkan melalui pendapat pakar dalam penilaian formatif atau disaat proses pengembangan berlangsung. Penilaian yang dilakukan pakar selaku validator adalah terkait dengan komponenkomponen modul ajar Bahasa Inggris yang sedang dikembangkan. Evaluasi formatif yang baik akan menghasilkan penilaian yang konsisten dan tanggapan yang positif dari pakar yang memvalidasi dengan skor penilaian Aiken V menunjukan skor rata-rata yang lebih tinggi dari 0.677 (Azwar, 2012). Penilaian ini dilakukan oleh 5 orang pakar yang merupakan akademisi bidang pendidikan dengan keilmuan pada media pembelajaran dan pembelajaran Bahasa Inggris yang dituangkan dalam angket penilaian validasi bahan ajar

Berdasarkan hasil penilaian pakar maka dapat dijelaskan rangkuman penilaian hasil validasi pakar pada bahan ajar Bahasa Inggris dapat dilihat pada tabel berikut:

Tabel 3 Rangkuman Hasil Validitas terhadap Bahan Ajar Bahasa Inggris

\begin{tabular}{cccc}
\hline $\begin{array}{c}\text { No. } \\
\text { Item }\end{array}$ & $\begin{array}{c}\text { Skor } \\
\text { V Aiken }\end{array}$ & Ket. & Hasil Aspek Penilaian \\
\hline Item 1 & 1.000 & Valid & Content \\
Item 2 & 0.933 & Valid & 0.889 (Valid) \\
Item 3 & 0.933 & Valid & \\
Item 4 & 0.800 & Valid & \\
Item 5 & 0.933 & Valid & \\
Item 6 & 0.867 & Valid & \\
Item 7 & 0.800 & Valid & \\
Item 8 & 0.933 & Valid & \\
Item 9 & 0.800 & Valid & Language Understanding \\
Item 10 & 0.800 & Valid & 0.893 (Valid) \\
Item 11 & 0.933 & Valid & \\
Item 12 & 0.867 & Valid & Valid \\
Item 13 & 0.933 & Valid & \\
Item 14 & 0.933 & & \\
\hline
\end{tabular}


Al-Ishlah: Jurnal Pendidikan - ISSN: 2087-949o (p); 2597-940X (e)

Vol. 12, No. 2 (2020)

\begin{tabular}{llll}
\hline Item 15 & 0.876 & Valid & \\
Item 16 & 0.933 & Valid & Presentation \\
Item 17 & 0.867 & Valid & 0.900 (Valid) \\
Item 18 & 0.867 & Valid & \\
Item 19 & 0.933 & Valid & \\
Item 20 & 0.933 & Valid & Writing Mechanics \\
\hline Item 21 & 0.933 & Valid & 0.883 (Valid) \\
Item 22 & 0.933 & Valid & \\
Item 23 & 0.867 & Valid & Valid \\
Item 24 & 0.800 & & \\
\hline
\end{tabular}

Berdasarkan tabel di atas dapat dijelaskan hasil validasi pakar pada bahan ajar Bahasa Inggris memiliki skor rata-rata validasi 0.889 pada komponen Content, skor 0.893 pada komponen Language Understanding, skor 0.900 pada komponen Presentation dan skor 0.833 pada komponen Writing Mechanics, dengan demikian seluruh komponen yang dinilai telah memiliki skor rata-rata validasi yang tinggi dari skor standar validasi yakni 0.677 dengan demikian bahan ajar Bahasa Inggris yang dikembangkan telah valid. Untuk lebih jelasnya, ratarata hasil validasi dapat dilihat pada histogram berikut ini:

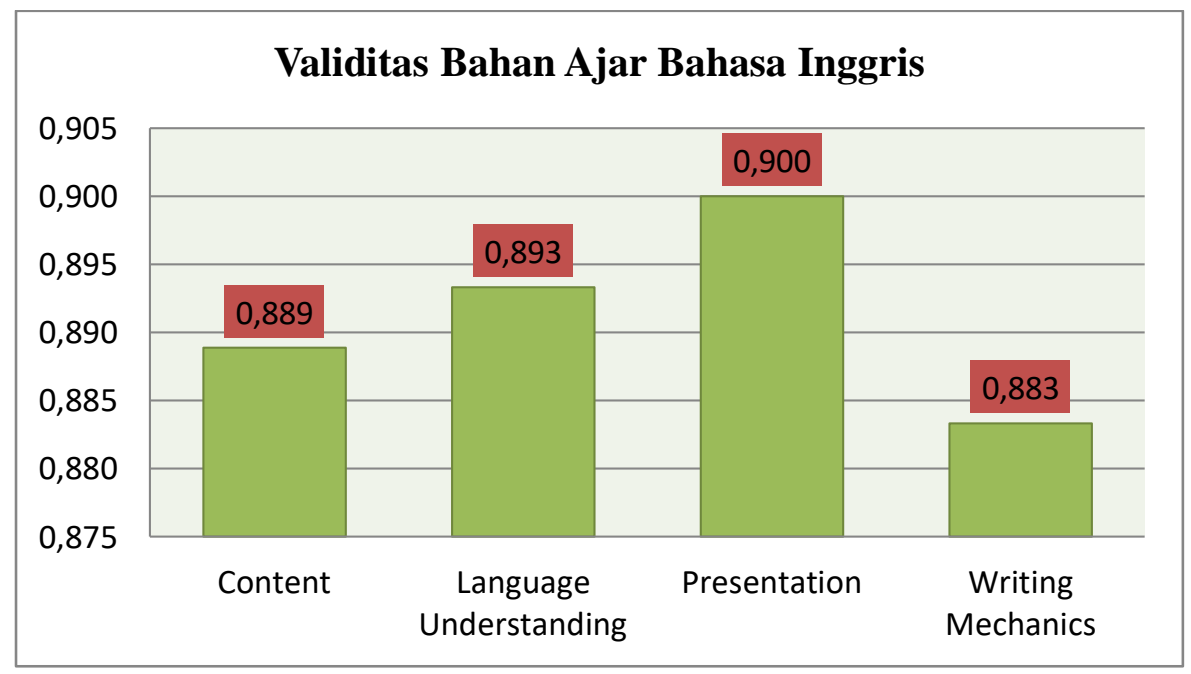

Grafik 1 Rata-rata Hasil Validitas

Hasil penelitian berikutnya adalah hasil Analisis Praktikalitas. Pengujian praktikalitas dilakukan untuk mengetahui kepraktisan penerapan bahan ajar poster presentation berbantuan vlog yang telah dikembangkan. Data praktikalitas didapat melalui penyebaran angket hasil belajar yang berjumlah 15 pernyataan yang diberikan kepada mahasiswa kelompok eksprimen. Rangkuman hasil praktikalitas dapat dilihat pada Tabel 4 berikut ini: 
Al-Ishlah: Jurnal Pendidikan - ISSN: 2087-949o (p); 2597-940X (e)

Vol. 12, No. 2 (2020)

Tabel 4 Hasil Praktikalitas Berdasarkan Rerata

\begin{tabular}{cccc}
\hline Rentang Skor & Kategori Praktis & Frekuensi (f) & $\%(\mathrm{f})$ \\
\hline $100 \%-90 \%$ & Sangat Praktis & 15 & 37,5 \\
$89 \%-80 \%$ & Praktis & 22 & 55 \\
$79 \%-65 \%$ & Sedang & 3 & 7,5 \\
$64 \%-55 \%$ & Kurang Praktis & 0 & 0 \\
$54 \%-0 \%$ & Tidak Praktis & 0 & 0 \\
\hline & Total & 40 & 100 \\
\hline
\end{tabular}

Berdasarkan analisis data persentase yang telah dilakukan dapat dijelaskan bahwa terdapat 15 orang $(37,5 \%)$ mahasiswa yang menyatakan bahwa bahan ajar sangat praktis, 22 orang (55\%) menyatakan praktis, 3 orang $(7,5 \%)$ menyatakan kurang praktis dan tidak ada mahasiswa yang menyatakan bahwa bahan ajar kurang atau tidak praktis. Sedangkan berdasarkan hasil rata-rata praktikalitas diperoleh hasil bahwa penilaian dari 40 orang mahasiswa yang belajar dengan bahan ajar dengan poster presentation berbantuan vlog memiliki penilaian ratarata sebesar $88 \%$ yang bermakna bahwa bahan ajar telah memiliki nilai praktis dari pendapat pengguna bahan ajar. Untuk lebih jelasnya dapat dilihat pada histogram berikut ini:

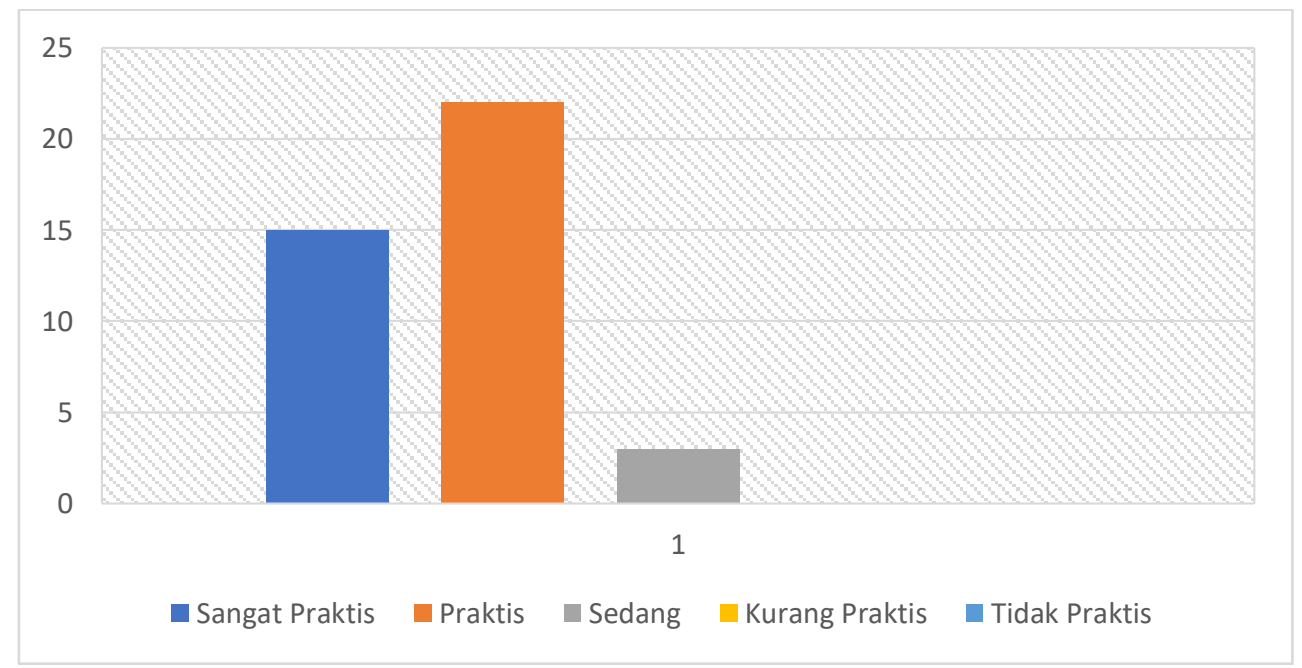

\section{Grafik 2 Histogram Penilaian Praktikalitas Bahan Ajar Poster presentation berbantuan Vlog}

Hasil penelitian selanjutnya adalah analisis efektivitas. Pengujian efektivitas dalam penelitian ini dilakukan dengan dua cara yaitu pengujian perbedaan hasil belajar pretest dan postest hasil belajar saat sebelum dan sesudah menerapkan bahan ajar Bahasa Inggris berbantuan poster presentation dan vlog, pengujian perbedaan hasil belajar kelompok kontrol yang belajar dengan menggunakan modul atau bahan ajar yang lama (konvensional) dan kelompok 
Al-Ishlah: Jurnal Pendidikan - ISSN: 2087-949o (p); 2597-940X (e)

Vol. 12, No. 2 (2020)

ekseprimen yang belajar menggunakan bahan ajar. Perbedaan hasil ini dijelaskan pada bagian berikut:

1. Uji Perbedaan Hasil Belajar Pretest dan Postest

Sebelum melakukan pengujian ini dilakukan dahulu uji Normalitas data melalui Uji Kormogorov-Smirnov (KS), dengan hasil sebagai berikut:

Tabel 5 Hasil Pengujian Normalitas Data

One-Sample Kolmogorov-Smirnov Test

\begin{tabular}{llrrrr}
\hline & & $\begin{array}{c}\text { Pretest_ } \\
\text { Kontrol }\end{array}$ & $\begin{array}{r}\text { Postest_ } \\
\text { Kontrol }\end{array}$ & $\begin{array}{c}\text { Pretest__ } \\
\text { Eksperimen }\end{array}$ & $\begin{array}{c}\text { Postest_ } \\
\text { Eksperimen }\end{array}$ \\
\hline $\mathrm{N}$ & & 40 & 40 & 40 & 40 \\
Normal Parameters & & & & \\
& Mean & 47.70 & 69.22 & 48.95 & 72.80 \\
& Std. & 13.211 & 10.519 & 19.119 & 14.807 \\
Most Extreme & Deviation & & & & .111 \\
Differences & Absolute & .095 & .146 & .111 & .150 \\
& Positive & .095 & .146 & .111 & .127 \\
Kolmogorov-Smirnov Z & Negative & -.080 & -.080 & -.073 & -.150 \\
Asymp. Sig. (2-tailed) & & .601 & .921 & .704 & .951 \\
\hline a. Test distribution is Normal. & .863 & .364 & .705 & .327 \\
\hline
\end{tabular}

Berdasarkan uraian hasil output analisis data normalitas dengan pengujian KS di atas dapat dijelaskan bahwa seluruh data yang akan diujikan memiliki distrubusi data Normal, karena memiliki nilai Asymp Sig. (2-tailed) yang >0.050. Pretest kelompok kontrol) 0.863, Postest kelompok kontrol 0.364, Pretest kelompok eksperimen 0.705 dan postest kelompok eksperimen 0.327. Dengan demikian dapat diartikan bahwa seluruh kelompok data berdistribusi data normal dan memenuhi syarat normalitas dalam melakukan uji t.

Uji perbedaan hasil pretest dan postest bermaksud untuk mengetahui perbedaan hasil dan peningkatan hasil belajar yang diperoleh kelompok kontrol dan kelompok eksperimen dengan menggunakan dua bahan ajar yang berbeda. Hasil analisis pada kelompok Kontrol dapat dilihat pada Tabel 6 berikut ini: 
Al-Ishlah: Jurnal Pendidikan - ISSN: 2087-949o (p); 2597-940X (e)

Vol. 12, No. 2 (2020)

Tabel 6 Hasil Analisis Pretest dan Postest Kelompok Kontrol

Paired Samples Test

\begin{tabular}{|c|c|c|c|c|c|c|c|c|c|}
\hline & \multicolumn{5}{|c|}{ Paired Differences } & \multirow[b]{3}{*}{$\mathrm{T}$} & \multirow[b]{3}{*}{$\mathrm{df}$} & \multirow{3}{*}{$\begin{array}{l}\text { Sig. } \\
(2- \\
\text { tailed })\end{array}$} \\
\hline & & \multirow[b]{2}{*}{ Mean } & \multirow{2}{*}{$\begin{array}{c}\text { Std. } \\
\text { Deviatio } \\
\mathrm{n}\end{array}$} & \multirow{2}{*}{$\begin{array}{l}\text { Std. } \\
\text { Error } \\
\text { Mean }\end{array}$} & \multicolumn{2}{|c|}{$\begin{array}{l}95 \% \text { Confidence } \\
\text { Interval of the } \\
\text { Difference }\end{array}$} & & & \\
\hline & & & & & Lower & Upper & & & \\
\hline $\begin{array}{l}\text { Pair } \\
1\end{array}$ & $\begin{array}{l}\text { Pretest_- } \\
\text { Kontrol } \\
- \\
\text { Postest__ } \\
\text { Kontrol }\end{array}$ & 21.525 & 15.215 & 2.406 & 26.391 & 16.659 & 8.948 & 39 & .000 \\
\hline
\end{tabular}

Berdasarkan Tabel 6 yang dikemukakan di atas dapat dijelaskan bahwa hasil pengujian perbedaan hasil belajar pretest dan postest kelompok kontrol memiliki skor t-hitung $>\mathrm{t}$-tabel $(\mathrm{df}=39)$, dengan nilai $8.948>2.021$. Karena thitung > t-tabel maka dinyatakan bahwa terdapat perbedaan hasil belajar sebelum (pretest) dan setelah (postest) belajar menggunakan modul pembelajaran konfensional. Rata-rata peningkatan hasil belajar dapat dilihat pada Tabel 7 berikut ini:

Tabel 7 Perbedaan Hasil Rata-rata Kelompok Kontrol (Pretest -Postest) Paired Samples Statistics

\begin{tabular}{llcrrr}
\hline & & & & \multicolumn{2}{c}{ Std. Error } \\
& & Mean & N & Std. Deviation & \multicolumn{1}{c}{ Mean } \\
\hline Pair 1 & Pretest_Kontrol & 47.70 & 40 & 13.211 & 2.089 \\
& Postest_Kontrol & 69.22 & 40 & 10.519 & 1.663 \\
\hline
\end{tabular}

Berdasarkan Tabel di atas terlihat bahwa hasil belajar kelompok kontrol saat pretest adalah 47.70 dan saat postest adalah 69.22. Hasil belajar meningkat sebanyak 21.52 skor. Hasil analisis pada kelompok Eksperimen dapat dilihat pada Tabel 8 berikut ini:

Tabel 8 Hasil Analisis Pretest dan Postes Kelompok Eksperimen

\begin{tabular}{|c|c|c|c|c|c|c|c|c|c|}
\hline & & & & aired $\mathrm{Sa}$ & mples Te & & & & \\
\hline & & & Pair & d Differe & nces & & & & \\
\hline & & & $\begin{array}{c}\text { Std. } \\
\text { Deviatio }\end{array}$ & $\begin{array}{l}\text { Std. } \\
\text { Error }\end{array}$ & $\begin{array}{r}95 \% \text { Co } \\
\text { Interva } \\
\text { Diffe }\end{array}$ & $\begin{array}{l}\text { fidence } \\
\text { of the } \\
\text { ence }\end{array}$ & & & Sig. \\
\hline & & Mean & $\mathrm{n}$ & Mean & Lower & Upper & $\mathrm{T}$ & $\mathrm{df}$ & (2-tailed) \\
\hline Pair & Pretest_ & & & & & & & & \\
\hline 1 & $\begin{array}{l}\text { Eksperimen } \\
\text { - Postest_- } \\
\text { Eksperimen }\end{array}$ & 30.700 & 13.838 & 2.188 & -35.126 & 26.274 & 14.031 & 39 & .000 \\
\hline
\end{tabular}


Al-Ishlah: Jurnal Pendidikan - ISSN: 2087-949o (p); 2597-940X (e)

Vol. 12, No. 2 (2020)

Berdasarkan Tabel 8 yang dikemukakan di atas dapat dijelaskan bahwa hasil pengujian perbedaan hasil belajar pretest dan postest kelompok eksperimen memiliki skor $\mathrm{t}$ hitung $>\mathrm{t}$ tabel $(\mathrm{df}=39)$, dengan nilai $14.031>2.021$. Karena $\mathrm{t}$ hitung $>\mathrm{t}$ tabel maka dinyatakan bahwa terdapat perbedaan hasil belajar sebelum (pretest) dan setelah (postest) hasil belajar menggunakan modul pembelajaran poster presentation berbantuan vlog. Rata-rata peningkatan hasil belajar dapat dilihat pada Tabel 5.8 berikut ini:

Tabel 9 Perbedaan Hasil Rata-rata Kelompok Eksperimen (Pretest -Postest)

\begin{tabular}{llcccc}
\hline \multicolumn{5}{c}{ Paired Samples Statistics } \\
\hline & Mean & N & Std. Deviation & $\begin{array}{c}\text { Std. Error } \\
\text { Mean }\end{array}$ \\
\hline Pair 1 & $\begin{array}{l}\text { Pretest_Eksperime } \\
\mathrm{n}\end{array}$ & 48.95 & 40 & 19.119 & 3.023 \\
\cline { 2 - 6 } & $\begin{array}{l}\text { Postest_Eksperime } \\
\mathrm{n}\end{array}$ & 79.65 & 40 & 12.831 & 2.029 \\
\hline
\end{tabular}

Berdasarkan Tabel di atas terlihat bahwa hasil belajar kelompok Eksperimen saat pretest adalah 48.95 dan saat postest adalah 79.65. Hasil belajar meningkat sebanyak 30.70 skor. Tingkat perbedaan hasil dapat digambarkan pada histogram berikut ini:

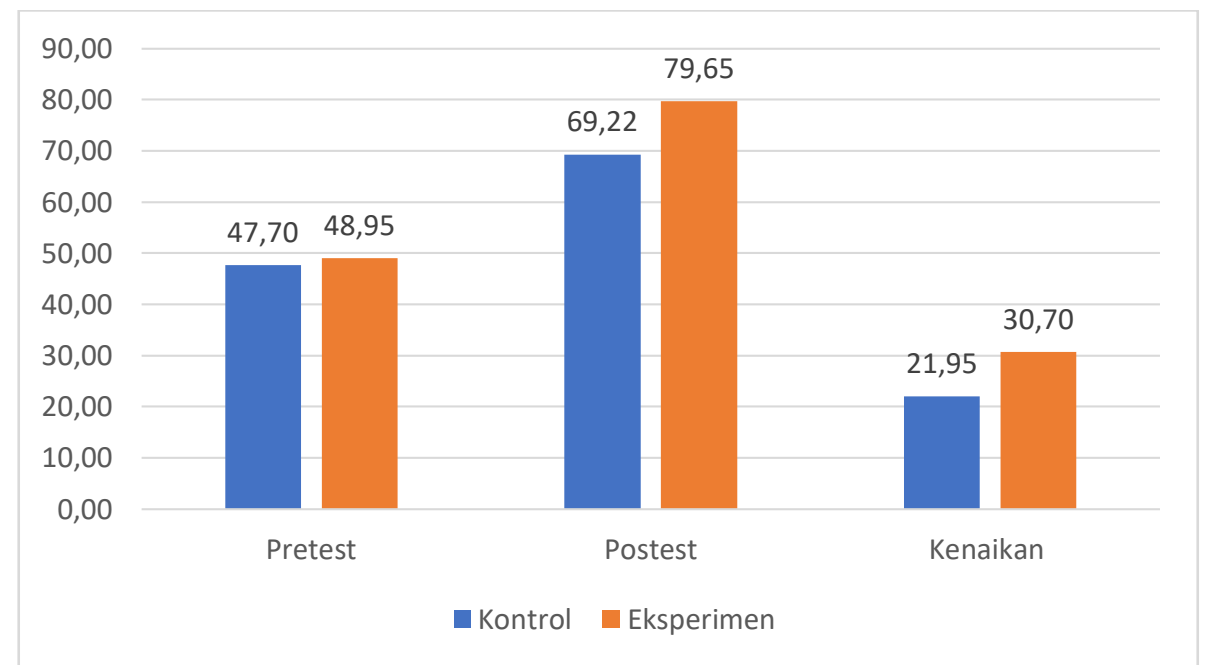

\section{Grafik 3 Perbedaan Hasil Rata-rata dan Selisih Pretest Postest}

Berdasarkan histogram perbedaan hasil rata-rata adalah selisih skor pretest postest pada kedua kelompok dapat dikemukakan hasil bahwa kelompok kontrol memiliki kenaikan hasil belajar sebesar 21,95 skor sedangkan mahasiswa yang belajar dengan modul poster presentation berbantuan vlog memiliki kenaikan skor hasil belajar sebesar 30,70. Hal ini bermakna bahwa mahasiswa lebih mampu meningkatkan hasil belajar dengan menggunakan bahan ajar poster presentation berbantuan vlog. 
Al-Ishlah: Jurnal Pendidikan - ISSN: 2087-949o (p); 2597-940X (e)

Vol. 12, No. 2 (2020)

2. Uji Perbedaan Hasil Belajar Kelompok Eksperimen dan Kontrol

Untuk mengetahui perbedaan hasil belajar antara kelompok kontrol dan ekperimen dilakukan uji beda dengan menggunakan Independent sample t test. Sebelum melakukan tes ini dilakukan uji homogenitas data untuk melihat apakah kelompok sampel eksperimen dan kontrol memiliki kemampuan yang sama seara statistik, Hasil uji homogenitas dapat dijelaskan sebagai berikut:

\begin{tabular}{|c|c|c|c|}
\hline \multicolumn{4}{|c|}{ Tabel 10 Hasil Pengujian Homogenitas } \\
\hline \multicolumn{4}{|c|}{ Test of Homogeneity of Variances } \\
\hline HASIL & & & \\
\hline $\begin{array}{l}\text { Levene } \\
\text { Statistic }\end{array}$ & df1 & $\mathrm{df} 2$ & Sig. \\
\hline 2.550 & 1 & 78 & .091 \\
\hline
\end{tabular}

Hasil pengujian homogenitas data melalui Levene Statistik menyatakan bahwa harga Signifikansi hitung 0.091 , skor ini $>0.050$ yang berarti bahwa kedua kelompok data memiliki karakteristik skor yang homogen. Untuk itu dapat dilakukan uji beda melalui independent sample t-test untuk pengujian hipotesis yang diajukan. Hasil analisis uji t dapat dilihat pada tabel 11 berikut ini:

Tabel 11 Hasil Uji Beda Hasil Belajar Kelompok Ekpserimen dan Kontrol Independent Samples Test

\begin{tabular}{ccccccccc}
\hline & $\begin{array}{c}\text { Levene's Test } \\
\text { for Equality of } \\
\text { Variances }\end{array}$ & & & & & & \\
& & & & & & & & \\
& t-test for Equality of Means & \\
\hline & F & Sig. & T & Df & $\begin{array}{c}\text { Sig. (2- } \\
\text { tailed) }\end{array}$ & $\begin{array}{c}\text { Mean } \\
\text { Difference }\end{array}$ & $\begin{array}{c}\text { Differenc } \\
\text { e }\end{array}$ \\
\hline $\begin{array}{c}\text { HASIL Equal variances } \\
\text { assumed }\end{array}$ & 3.522 & .064 & 3.974 & 78 & .000 & 10.425 & 2.623 \\
$\begin{array}{l}\text { Equal variances } \\
\text { not assumed }\end{array}$ & & & 3.974 & 75.110 & .000 & 10.425 & 2.623 \\
\hline
\end{tabular}

Hasil pengujian hipotesis melalui uji independent sample t-test di atas menunjukkan hasil bahwa $t_{- \text {hitung }}>\mathrm{t}_{\text {-tabel }}(\mathrm{df}=78)$ dengan skor $3.974>1.990$, dengan demikian hipotesis yang berbunyi terdapat perbedaan hasil belajar mahasiswa yang belajar menggunakan bahan ajar poster presentation berbantuan vlog memiliki hasil belajar yang lebih baik dari mahasiswa yang belajar menggunakan modul biasa (konvensional) pada taraf signifikansi 95\%. Untuk itu dinyatakan bahwa bahan ajar ini efektif digunakan untuk meningkatkan hasil belajar Bahasa Inggris mahasiswa. 
Al-Ishlah: Jurnal Pendidikan - ISSN: 2087-949o (p); 2597-940X (e)

Vol. 12, No. 2 (2020)

\section{SIMPULAN}

Berdasarkan hasil penelitian yang telah dikemukakan, maka dapat simpulkan bahwa analisis kebutuhan (need analysis) menunjukan bahwa mahasiswa jurusan sistem informasi fakultas ilmu komputer UPI YTPK Padang membutuhkan bahan ajar Bahasa Inggris 1 yang self study dan komunikatif. Hasil belajar kelompok experiment dengan menggunakan bahan ajar yang telah dikembangkan lebih baik daripada kelompok kontrol yang diajar tanpa mengunakkan bahan ajar dengan selisih sebesar 8,75 point. Telah dilakukan validasi oleh dosen-dosen pengampu mata kuliah Bahasa Inggris sebanyak 5 orang. Berdasarkan validasi yang telah dilakukan adanya saran terhadap penyempurnaan bahan ajar yang dikembangkan tersebut. Dan bahan ajar yang dikembangkan berbantuan poster presentation dan vlog memiliki validitas, praktikalitas dan efektivitas yang layak digunakan untuk pembelajaran mata kuliah Bahasa Inggris 1.

\section{DAFTAR PUSTAKA}

Abdi, U. R. (2012). Metodologi Penelitian Sosial dan Ekonomi. Bandung: Alfabeta.

Arikunto, S. (2010). Manajemen Penelitian. Jakarta: Rineka Cipta.

Azwar, S. (2012). Reliabilitas dan Validitas (Edisi 4). Yogyakarta.Pustaka Belajar.

Balakrishnan, V. D. \& Puteh, F. (2014). Blending Face-to-Face Communication and Video-Blogging in Acquiring Public Speaking Skills. Journal of Creative Practices in Language Learning and Teaching, 2(1), 64-72.

Duddley-Evans, T. and, \& M.J.St. John. (2009). Development in English for Specific Purposes Dudley Evan. Cambridge: CUP.

Forester, L. A., \& Meyer, E. (2015). Implementing Student-Produced Video Projects in Language Courses (Vol. 48). Retrieved from http://digitalcommons.hope.edu/faculty_publications/1421

Gao, W., Tian, Y. \& Huang, T. (2010). Vlogging: A Survey of Videoblogging Technology on the Web. ACM Computing Surveys, 42(4), 1-57.

Hung, S. (2011). Pedagogical Applications of Vlogs: An Investigation into ESP Learners' Perceptions. British Journal of Educational Technology, 42(5), 736-746.

Lambert, I. (2012). Assessing Oral Communication: Poster presentations.

Miller, J. E. (2007). Preparing and Presenting Effective Research Posters. Health Services Research, 42(1 $\quad I)(11), \quad 311-328$. https://doi.org/http://doi.org/10.1111/j.1475-6773.2006.00588.

National Society for Experiential Education. (2013). 8 Principles. Retrieved from http://www.nsee.org/8- principles 
Al-Ishlah: Jurnal Pendidikan - ISSN: 2087-949o (p); 2597-940X (e)

Vol. 12, No. 2 (2020)

Noytim, U. (2010). Weblogs Enhancing EFL Students' English Language Learning. Procedia Behavioral Sciences, 2, 1127-1132.

Plunkett, S. W. (2010). Tips on poster presentations at professional conference. Retrieved from http://www.csun.edu/ cor/templates.html

Sugiyono. (2011). Metode Penelitian Pendidikan (pendekatan kuantitatif, kualitatif dan R\&amp;D). Bandung: Alfabeta.

Tim Puslitjaknov (Pusat Penelitian Kebijakan dan Inovasi). (2008). Metode Penelitian Pengembangan. Jakarta: Depdiknas.

W. R. Borg and M. D. Gall. (1989). Educational Research: An Introduction. New York: Longmen.

Watkins, J. (2012). Increasing Student Talk Time through Vloging. Language

Education in Asia, 3(3), 196-203. 